\title{
Spændingsfeltet mellem psykoanalyse og poststrukturalisme
}

\section{Af Kirsten GrønbæK Hansen}

Hvis Foucault havde ret, tog Frend da fejl? Og hvis Freud tog fejl, hvad tog han da fejl af? Af psykoanalysen, måske? Både poststrukturalismen og psykoanalysen tilbyder forstålser af køn og peger på, at disse forstå lser ikke behøver at udelukke hinanden, men tvartimod beskaftiger sig med forskellige dimensioner, der griber ind $i$ binanden og betydningsfylder binanden.

\section{E S S A Y}

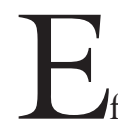

fter det store boom i kønsforskningen i 70'erne har det gennem de seneste tiår været som lå den underdrejet på forskningsinstitutionerne. Det har været svært at tiltrække studerende til kurser om køn og den mainstreaming der skulle bringe kønsspørgsmålet ind i de forskellige fag og discipliner synes knap at have fundet sted. Inden for psykologien, som er det felt jeg kender bedst, er det i det mindste sådan at køn stille er gledet ud som tema fra kurser om udvikling, personlighed og andet, sådan at man kan fortsætte som før 70erne.

I de seneste år er der imidlertid kommet røre i kønsdebatten på universiteterne igen. Om ikke andet, så blandt studerende og unge forskere. Dette er hovedsageligt sket i forbindelse med den poststrukturalistiske bølge, således at det også er gennem poststrukturalistiske tilgange, at dagsordenen for debat og analyse af kønnets betydning sættes. 
Jeg tror der er flere grunde til denne alliance mellem kønsforskning og poststrukturalisme, også flere end de, jeg vil komme ind på her. Der er sikkert også mange grunde til, at kønsforskningen forstummede i begyndelsen af 80'erne, men en af dem var måske en vis teoretisk afmatning. Der var efterhånden sagt, hvad der var at sige, med te. Der argumenteres desuden for at psykoanalysen kan bidrage til forståelse af kønnede handlinger og tolkninger på en måde, der kan ses som et bidrag til den poststrukturalistiske forståelse, ikke uden at bryde dennes grænser - så ville der jo ikke være vundet noget - men dog uden at kunne skrives ind i de ovennævnte kategorier.
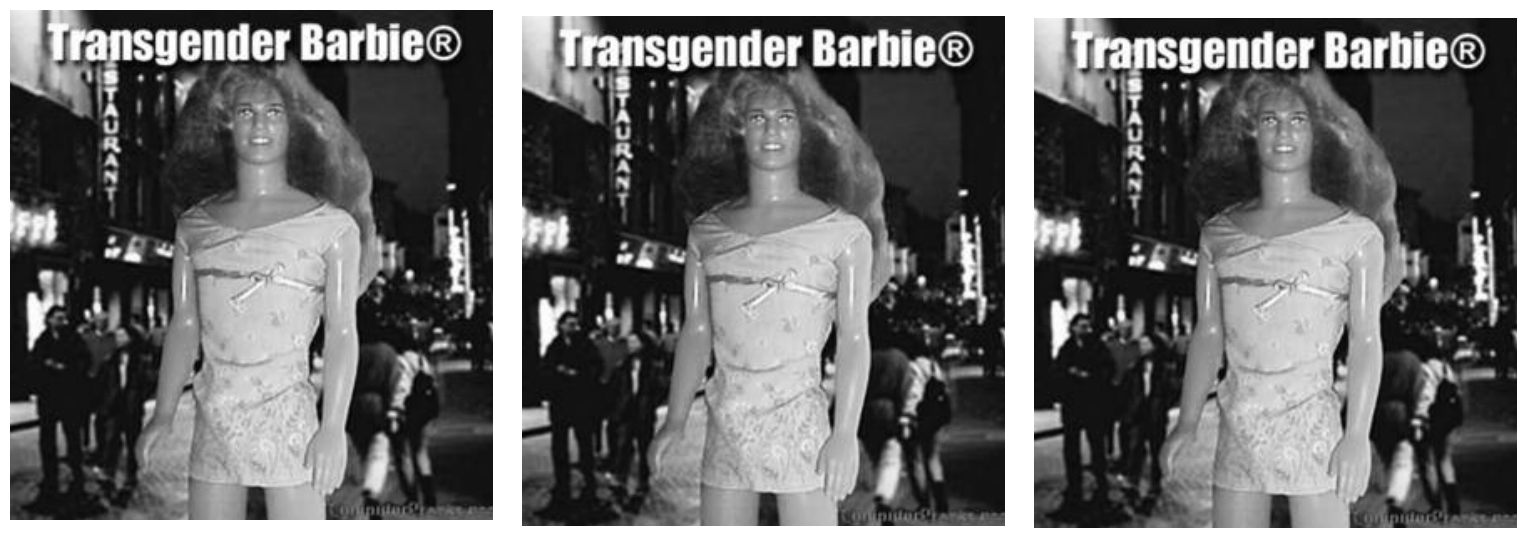

de teoretiske redskaber man havde og dette, sammen med en generel recession i den politiske kamp for ligestilling og emancipation, kan ses som baggrund for den tavse periode.

I den poststrukturalistisk inspirerede kønsforskning bliver psykoanalysen ofte tildelt positionen som den "anden", som en tænkning der er alt det, man som poststrukturalist må lægge afstand til. Essentialisme, determinisme og konventionalisme hører ofte med i kategoriseringen af psykoanalysen. I dette essay argumenteres der for, at psykoanalysen ikke nødvendigvis fører til essentialistiske, deterministiske og konventionelle forståelser af køn, men tværtimod i sit udgangspunkt kan ses som et opgør med det-

\section{POSTSTRUKTURALISMEN}

\section{- KORT FORTALT}

Som kønsforsker må man byde poststrukturalismen velkommen, dels som en spiller, der kan være med til at genoplive en vigtig akademisk diskussion, dels som en medspiller, der kan udfordre og medvirke til at videreudvikle teorier om køn og som kan åbne nye områder for empirisk granskning af kønnenes mange betydninger.

Når kønsforskningen igen får et gennembrud i poststrukturalistisk udgave hænger det sandsynligvis sammen med poststrukturalismens intentioner om at dekonstruere akademiske diskurser, at vise dem som - om ikke arbitrære - så dog som diskursive konstruktioner, der er resultater af sociale forhandlinger i forskerfællesskabet, og som făr 
deres legitimitet gennem den snævre sammenhæng mellem magt og viden. Vi har ingen adgang til forskningens genstandsfelt uden gennem de diskurser vi forhandler frem, lærer poststrukturalismen os. I den forstand udfordrer poststrukturalismen den akademiske selvforståelse, idet den underminerer dens påberåben sig objektivitet og som rationel, objektiv og impartial. De konventionelle diskurser om køn, der dikotomiserer maskulint og feminint i en hegemonisk relation, fastholder en sammenhæng mellem feminint og irrationelt, feminint og subjektivt og feminint og emotionelt.

Jeg er opmærksom på, at jeg her får be-
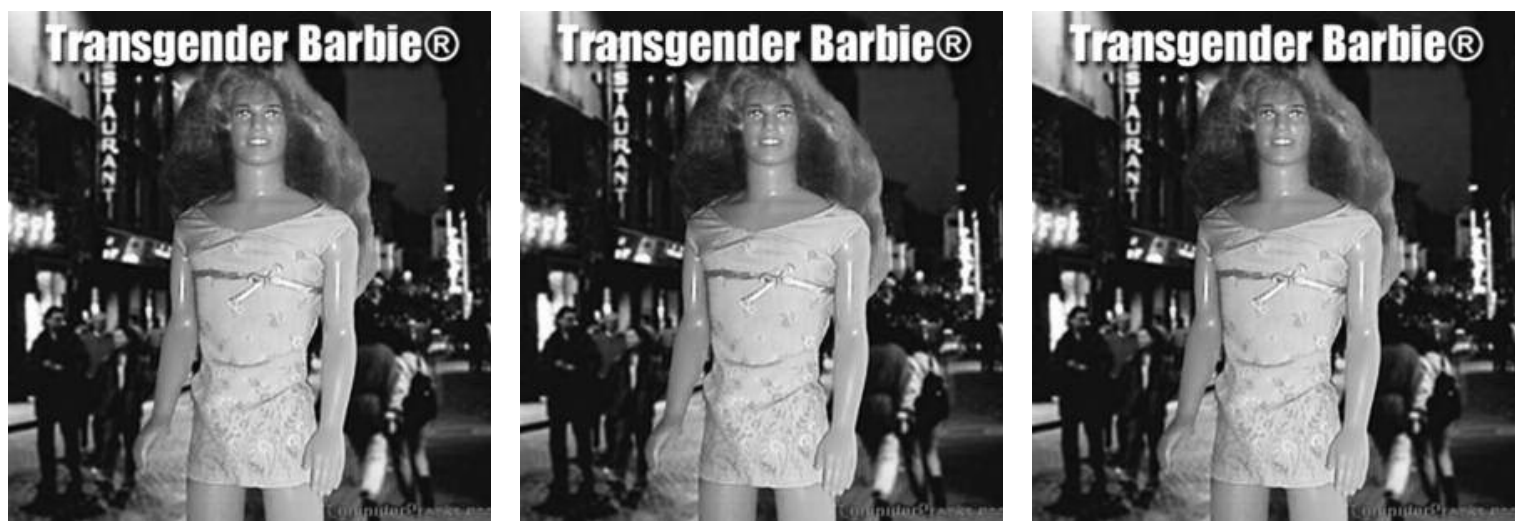

impartialitet. Samtidig er det stadig sådan, at kønsforskning fortrinsvis er en beskæftigelse, kvinder giver sig af med - selv hvor kønsforskningen handler om maskuliniteter.

Det er nok ikke så sært, at det er sådan. Det er kvinder, der har noget på spil her. For det første ved at de i vid udstrækning er ekskluderet fra de mere magtfulde positioner i de vidensproducerende institutioner; det bliver for eksempel tydeligt i de rapporter der netop er kommet fra forskningsinitiativet "Kønsbarrierer i de højere uddannelser og forskning". " For det andet fordi kvinder gennem konventionelle diskurser om køn tilskrives netop de kvaliteter, der står i modsætning til de akademiske dyder. Traditionelt forstår videnskaben sig selv skrevet poststrukturalismen, som var den en entydig metateoretisk ramme, som man kan slutte op om, eller lade være. Sådan er det naturligvis ikke, der er en mangfoldighed af forskellige positioner hos poststrukturalistiske tænkere, men også nogle fællestræk, som jeg her tager udgangspunkt i. Der er en afvisning af at den viden vi producerer, er en sand afspejling af den virkelighed, vi mener at beskrive gennem vore diskurser. Diskurser afslører ikke sandheder bag fremtrædelser. Her markerer poststrukturalismen sig klart i modsætning til marxismens intension om at søge væsensformer bag fremtrædelsen. Viden er et resultat af sociale og kulturelle processer og er txt forbundet med magt, således at man kan tale om vidensregimer. De kategorier vi forstår 
verden med er således bevægelige og midlertidige idet de ikke peger tilbage på reelle fænomener, men forbinder sig med andre kategorier i et netværk af mere eller mindre sammenhængende diskurser. At træde op mod de diskurser, der præsenterer sig som viden, er altså at træde op mod vidensregimer, at forsøge at forhandle nye diskurser. Nye magt/viden forhold kan således destabilisere de aktuelt tilgængelige kategorier, og det er netop en sådan destabilisering poststrukturalismen tilbyder. Gennem vor diskursive tilgang sker en inkludering og ekskludering - nogle handlinger bliver mulige og forståelige, andre ikke, og det er det ekskluderede som poststrukturalismen vil skabe rum for.

I poststrukturalistisk forstand representerer kvinder det, der fraspaltes de videnskabelige institutioner, hun bliver andetheden, det som destabiliserer de akademiske diskurser. Det bliver så fra den position kønsforskningen kommer til at tale og med poststrukturalismen kommer den netop til at påtage sig den position, som gjorde, at den måtte fraspaltes i første omgang. Den dekonstruerer rationaliteten i videnskabelige teorier og viser deres sociokulturelle udspring. Den påtager sig i en vis forstand subjektiviteten, idet den viser objektiviteten som et blændværk. Her ville jeg jo gerne have fortsat listen med at tale om emotionalitetens åbne tilsynekomst; men det ville ikke være sandt, selvom det ville have givet en konventionelt smukkere afrunding af mit ærinde. Poststrukturalismen udfordrer ganske vist forestillingen om den impartielle forsker og peger på at der er interesser på spil, men den gør sig kun sporadiske tanker om det emotionelles rolle i konstruktionen af videnstilbud.

Det ændrer dog ikke ved det forhold, at der er gode grunde til, at kønsforskningen og poststrukturalismen hænger så godt sammen og at de så at sige bærer hinanden frem. Det er her den marginaliserede stemme kan komme til orde.

For mig at se, er dette både indlysende og godt. Poststrukturalismen giver os nogle redskaber til at åbne for nye tolkninger af kønnets betydning, og til at finde sprækkerne i de eksisterende diskurser om køn; diskurser, der både begrænser os i vore bestræbelser på at finde nye subjektive udtryk ved at indskrænke omfanget af de mulige positioner vi kan indtage, og som bestandig fastlåser de tolkningsrammer, der er med til at bestemme andres forståelse af vores handlinger, ja vore egne for den sags skyld.

Inden for psykologien, diskuterer poststrukturalister især hvordan subjektivitet kan forstås og i hvilken udstrækning og hvordan subjektet har aktørstatus. Foucault (1972 og 1970) har haft en stor betydning i etableringen af den poststrukturalistiske bevægelse, og nogle af Foucaults værker kan tolkes som om subjektivering kun kan foregå gennem subjektets indtræeden i den temmelig træge og stabile diskursive orden. Om Foucault nu bør tolkes på den måde, vil jeg undlade at tage stilling til, det er som om Foucault unddrager sig en endelig tolkning. Ikke desto mindre er det blandt andet her man finder nogle vigtige forskelle mellem poststrukturalistiske forskere: i hvilken udstrækning er diskurserne ressourcer man kan trække på i sin konstruktion af sig selv og andre og i hvilken udstrækning er vi nødvendigvis et resultat af diskursive konstruktioner. Da poststrukturalistiske psykologer i sagens natur interesserer sig for subjektiveringsprocesser, er denne diskussion meget væsentlig og man kan se en vifte af forskellige tolkninger, der giver mere eller mindre rum for subjektive tolkninger af diskurser (se f.eks. Davies/Harré 1990 og Søndergaard 2002). Det er ikke mit ærinde at gå ind i denne diskussion, blot vil jeg pege på at hvor det tidligere var sådan, at poststrukturalismens afvisning af at tale om noget inde i mennesket, gjorde det vanskeligt at inddrage erfaringer og tilbøjeligheder, er der nu lukket op for en diskussion af dette ved at der tales om erfaringer med forskellige positioneringer eller direkte om desire-strukturer. 


\section{ET PSYKOANALYTISK BUD}

\section{PÅ FORSTÅELSE AF KØN}

De muligheder poststrukturalismen tilbyder er nødvendige, men ikke tilstrækkelige til at forstå de kønnede handlinger og tolkninger. Der er noget vigtigt, der undslipper os, som allerede antydet, nemlig den emotionelle betydning af de konventionelle diskurser vi skriver os ind $i$, den emotionelle betydning af de positioner vi indtager eller kæmper for at få lov at indtage. Det, der marginaliseres eller ekskluderes af de sproglige diskurser, hører ikke op med at eksistere, fortæller psykoanalysen os. De lever videre i det ubevidste, i fantasien, i kroppen. Holder vi os til de muligheder poststrukturalismen foreskriver, giver vi afkald på at forstå de livshistoriske erfaringer som medspillere i de subjektive tolkninger og i de begærspositioner som subjektet indtager. Erfaringer er ikke bare mængden af de positioneringer subjektet bliver en del af i løbet af livet, de struktureres og bearbejdes på baggrund af den subjektive betydning de har for subjektet.

Ved at insistere på, at ville tale om noget indre, overskrider psykoanalysen naturligvis det poststrukturalistiske projekt, men det behøver ikke at betyde essentialisme eller determinisme. Men det afhænger naturligvis af $\mathrm{i}$ hvilken aftapning vi finder psykoanalysen - og der er mange at vælge imellem. I bogen Psychoanalytic Culture (1997) viser Ian Parker, hvordan afledninger af psykoanalytisk tænkning gennemsyrer de vestlige samfund, således at det næsten er umuligt at tænke over sig selv og relationer til andre, uden om en psykoanalytisk præget diskurs. Psykoanalytiske elementer er blevet optaget i hverdagens diskurser om psykologiske emner, men der er meget langt mellem den hverdagsforståelse af psykoanalyse, som Parker påviser og den psykoanalyse, der udvikles og praktiseres - og så er der igen stor forskel på de forskellige udviklinger af psykoanalyse der opstod i kølvandet på Freuds arbejde. Alfred Lorenzer er en af de analytikere, der har begivet sig ind i den ikke ukendte sport, at fremskrive hvad Freud i virkeligheden ville sige os (Lorenzer 1974). I hvilken udstrækning Freud ville være enig, er der ingen grund til at gxtte på, men jeg vil i det følgende tage udgangspunkt i Lorenzers tolkning af psykoanalysen, netop fordi han fastholder det relationelle og situerede perspektiv i sin forståelse af subjektiveringsprocesserne, fordi han peger bort fra en entydig barndomsdeterminisme og endelig fordi hans forståelse af sproget og sprogliggørelsen af interaktioner og scener på en og samme gang peger mod en forståelse af de diskursive regimers betydning i den løbende dannelse af subjektivitet og mod de af diskurserne ekskluderede erfaringers videre liv og mulighed for at blande sig i de diskursive processer.

At medtage subjektivt bearbejdede erfaringer, betyder ikke nødvendigvis at man antager en entydig kausal sammenhæng mellem den aktuelle subjektivitet og de livshistoriske erfaringer. Livshistorie er ikke skæbne, skønt det tolkes sådan i nogle psykoanalytiske aftapninger. For det første er de interaktioner subjektet deltager i mangfoldige og mangetydige, Alfred Lorenzer (1977) taler om sceniske erfaringer, som netop overskrider de diskursive lag af oplevelsen, og hvor den subjektive bearbejdning kan betyde nytolkning af også det, der er diskursivt ordnet. For det andet er der ikke nogen entydig forbindelseslinie fra fortid til nutid. Allerede i sine tidligste skrifter, i sine breve til Fliess introducerer Freud begrebet Nachträglichkeit (Freud 1986). Han peger på, at et erindringsspor kan gennemgå en omordning i lyset af nye erfaringer. Livshistoriske erfaringer er ikke gjort en gang for alle, men er bevægelige og kan få nye subjektive betydninger i lyset af nutidens muligheder og interaktioner. 


\section{PSYKOANALYSENS TRADITION FOR FORSTÅELSER AF KØN}

Inden jeg giver mig til at argumentere for en sådan dobbeltstrategi i analysen af kønnede handlinger og tolkninger, vil jeg kort pege på dele af psykoanalysens mere traditionelle bidrag til forståelse af køn. Her vil jeg hævde, at allerede den mere traditionel- de mindre sammenhængende daglige fortællinger om køn.

Psykoanalysen er aldrig blevet tavs om kønnet, gennem kønsforskningens tidlige begejstrede fase, gennem recessionen og nu med kønsforskningens genopblussen taler psykoanalysen ufortrødent om køn. Det gør
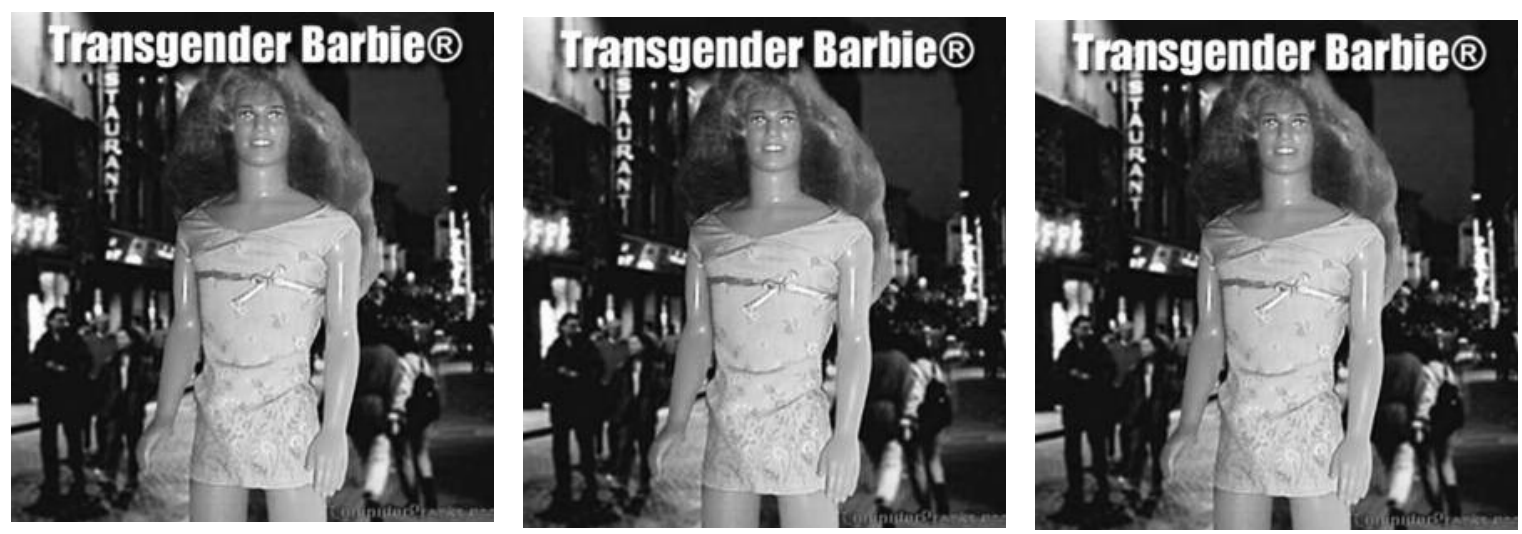

le psykoanalytiske forståelse af kønnets tilblivelse videregiver nogle indsigter, der ikke strider mod de poststrukturalistiske forståelser, men måske tværtimod kan ses som foregribende disse. Psykoanalysen fokuserer på andre niveauer end poststrukturalismen, men de to niveauer griber ind $\mathrm{i}$ hinanden, betydningsfylder hinanden og bliver betingelser for hinanden.

Diskurssætningen af køn giver mulighed for at gøre køn på bestemte måder og umuliggør andre måder at gøre køn på. Det er blandt andet disse umulige måder at gøre køn på, som psykoanalysen muligvis kan være med til kaste lys over: det som unddrager sig diskursen, det som sniger sig ind i sprækkerne af de tilsyneladende konsistente videnskabelige diskurser om $\mathrm{k} ø \mathrm{n}$ og den på mange forskellige måder afhængigt af hvilken tolkning det drejer sig om, men vender man blikket mod Freuds arbejder, kan man se at kønnet allerede her, ved sidste århundredes begyndelse, trækkes bort fra den essentialistiske forståelse, der var den tids gængse. Maskulinitet og feminitet er ikke en kroppen iboende kvalitet, der med nogen naturnødvendighed vil vise sig i løbet af subjektets liv. På linie med Simone de Beauvoir er kvinde noget man bliver, oven i købet ofte modstræbende. Freud (se f. eks. 1972) advarer imod at tolke libidoens forskellige mål, som for eksempel aktiv/passiv som mandlig/kvindelig, tværtimod peger han her på at det blot ville være at føje konventionen, og af det lærer vi ikke noget nyt. 
Når Freud derefter går i gang med at beskrive, hvordan det går til at små piger udvikler sig til kvinder og små drenge til mænd, med kønnenes konventionelle karaktertræk, og endda gør opdagelsen af den biologiske forskel ansvarlig for at det sker, bliver den konventionelle kønnethed uafvendelig (bortset fra nogle få muligheder
(2000), at en konsekvent psykoanalytisk forståelse ville afsløre begxret af en "ting" som noget andet, end det giver sig ud for. Det viser hen til et andet begær, som tingen bliver symbol for. "Tingen” er en kreation, subjektet har skabt den, og her kan vi pege på Winnicotts paradox (1972), at de objekter man skaber sig subjektivt, på en
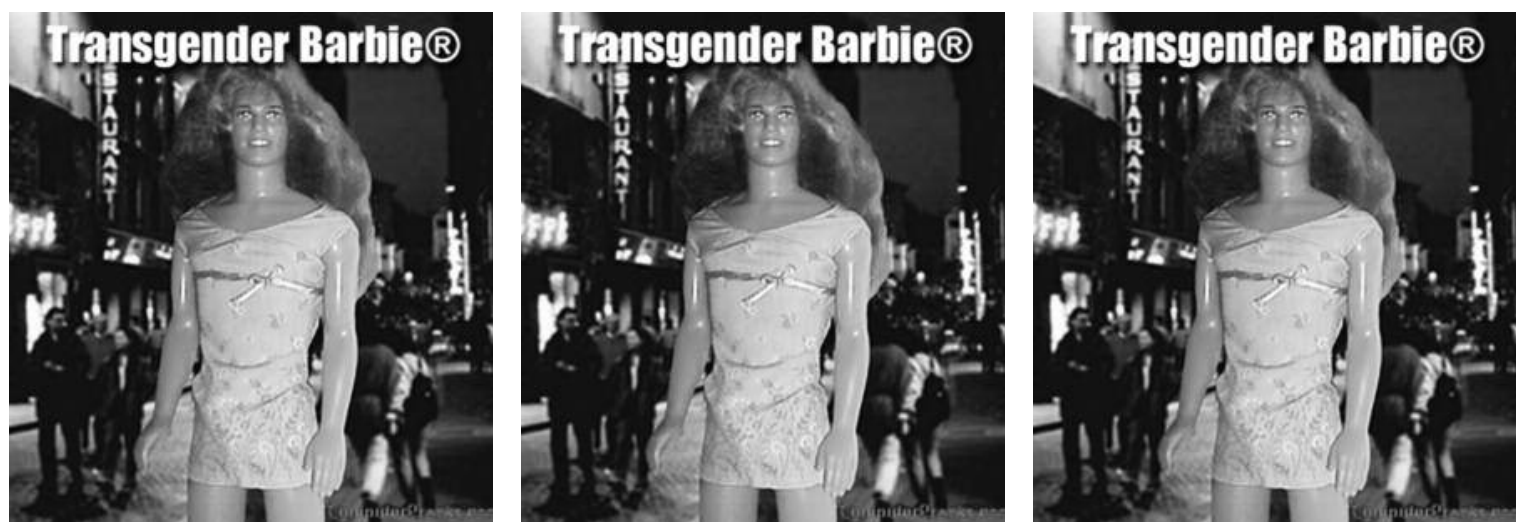

for afvigende udvikling) og den bliver knyttet til det biologiske køn. Men ikke som en forestilling om en essentiel mandlighed eller kvindelighed; kønnet ligger ikke inde i subjektet og venter på at komme til udfoldelse. Biologien (her penis) er et tegn, der tolkes af subjektet og som resulterer i en bestemt driftsstrukturering.

Freuds beskrivelse af udviklingen af kønnethed blev meget tidligt imødegået af ikke mindst - kvindelige analytikere, hvor flere af dem peger på, at Freud med sin beskrivelse af for eksempel penismisundelsen, som den drivende kraft bag kvindens driftsskæbne, ikke benytter sine egne indsigter. En konsekvent psykoanalytisk holdning ville have bragt hans analyse et andet sted hen. For eksempel hævder Maria Torok gang skal findes og skabes. Her lader penis sig finde som en kulturel realitet (så real som et symbol nu kan være). Den stiller sig til rådighed som symbol.

Allerede her kan man se, hvordan de kulturelle symboler begynder at blande sig i begærskonstruktionen. Man kunne også sige: hvordan de konventionelle og magtfulde diskurser stiller sig til rådighed $\mathrm{i}$ den subjektive betydningsdannelse og helt ind $\mathrm{i}$ begærskonstruktionen. Begæret kommer til syne i konventionelle narrationer og diskurser. Poststrukturalisterne fortæller os, at vi ikke har nogen prædiskursiv adgang til at forstå kroppen (Butler 1993) og den pointe synes Torok ikke at modsige, men at understrege: vi har heller ingen prædiskursiv ad- 
gang til at forstå begæret. Det træder frem i diskursiv form og forklædning. Med den sidste bemærkning, om forklædningen, overskrides poststrukturalismens rammer, idet det hævdes at vi kan finde "noget" bag begærets diskursive forklædninger. Hvad dette noget er, lader sig imidlertid ikke udlede direkte eller udtømmende. Vi kan ikke slutte fra livshistoriske erfaringer eller direkte fra kulturelle eller samfundsmæssige strukturer. Vi kan nærme os det tøvende og prøvende, men med psykoanalysen kan man hævde, at begæret, så at sige, ikke går op i den diskursive orden - heller ikke når den er kønnet. De libidinøse ønsker og fantasier er så varierede og så mangfoldige, at de ikke lader sig begribe eller bare gribe af de diskurser og narrationer, der kulturelt står til rådighed. Men netop dette "noget" kan være på spil, når de diskursive ordener brydes og modsiges, når subjektpositioneringer forsvares, afvises eller konstrueres på nye måder. Det behøver ikke at være til det bedre; de libidinøse ønsker og fantasier behøver ikke være progressive eller emanciperende; men de udgør det lag, som den kreative omgang med de kulturelle diskurser trækker på.

Det med at sammentænke poststrukturalisme med psykoanalyse er ikke et helt originalt projekt. I de fleste tilfælde sker der en kobling til Lacan, der på grund af den sproglige vending han foretager i sin psykoanalysetolkning, inviterer til en sådan kobling. Judith Butler tager afsæt i en Lacansk tænkning og lægger afstand til den (Butler 1990), men dog ikke mere, end at flere af de lacanske begreber fastholdes. Valerie Walkerdine (1997), hvis arbejder jeg i øvigt har fundet meget inspirerende, fastholder en art dobbeltanalyse i sine arbejder, hvor den poststrukturalistiske er den ene og den lacanske den anden. Dette for eksempel hvor hun analyserer arbejderklassepigers brug af populærlitteratur og foruden analysen af kulturens diskurser undersøger de begærspositioner, der indgår i pigernes anvendelse og som ikke udtømmes gennem en analyse af diskurser. Der kunne nævnes andre, for eksempel Nancy Chodorow (1999), der kobler til poststrukturalistisk tænkning fra en mere objektrelationsteoretisk forståelse af psykoanalysen. På vore hjemlige breddegrader, er også Harriet Bjerrum Nielsen (1994) og Monica Rudberg (1994) begyndt en dialog med poststrukturalismen fra et mere objektrelationsteoretisk standpunkt på grundlag af et større empirisk projekt.

\section{ET KRITISK TEORETISK UDGANGSPUNKT}

Når jeg vælger at forsøge koblingen fra en kritisk teoretisk position, med udgangspunkt i Alfred Lorenzers bidrag (1970) til en gentolkning af psykoanalysen, er det ikke blot på grund af en gammel kxrlighed til Lorenzers projekt. Det er det naturligvis også, men i Lorenzers fundamentale antagelser om subjektivitetens løbende dannelsesproces bliver det muligt at se subjektiviteten som flydende, som i bestandig dannelse og omdannelse, og ikke mindst gør hans forståelse af sproget det muligt at se dette både som en del af de kulturelle og samfundsmæssige diskurser og som noget der kan have klangbund i det, der er ekskluderet af de sproglige interaktionsformer.

Lorenzer beskæftiger sig kun sporadisk med køn, men det tematiseres naturligvis hos ham, som det gøres hos alle psykoanalytikere. Det væsentlige er her, hvordan han skriver sig ud af den subjekt/objekt dualisme, man let kan ende i, og hvordan han viser muligheden for det marginaliserede, det ikke-diskursivt omsætteliges tilsynekomst. Hvor psykoanalysen traditionelt taler om at objekter besættes libidinøst, sådan at den ydre verdens objekter (mennesker) kan være materiale bag en række indre objekter, da taler Lorenzer om hele interaktionsformer, der besættes libidinøst. Det er relationerne og de relationelle handlinger, der danner basis for de subjektive strukturer, der konstituerer subjektiviteten. Barnet vil 
naturligt nok blive inddraget i konventionelle interaktioner, men også i interaktioner, der ikke er det. I det sanselige konkrete samspil med barnet - og senere den voksne - vil kulturelt marginaliserede forholdemåder også forekomme.

Allerede den barnlige subjektivitet bliver således mangfoldig og de erfaringer de afsætter er sceniske i den forstand, at de indeholder hele situationer med disses mangfoldighed af sanseindtryk. Sproget gives en afgørende rolle. Når sproget på et tidspunkt for alvor træder frem på scenen vil det tendentielt ordne og organisere livsytringerne (Lorenzer 1981). Der er noget der kan siges og andet der ikke kan sættes på sprog. Barnet træder ind i den diskursive orden, der naturligvis hele tiden har været tilstede, idet den har været med til at regulere forældres og andres relationer og interaktioner med barnet. Det er også med sproget at kønnet for alvor træder frem, barnet bliver i en vis forstand fanget i kønskategorier. Hermed træder også kønnenes konnotationer i kraft og pigen må gøre sit køn for at blive anerkendt som interaktionsdeltager, og drengen må gøre det samme. Der er naturligvis ikke bare én måde at gøre køn på, men der vil være visse rammer barnet må holde sig inden for, hvis det ikke vil ekskluderes af det gode selskab.

For så vidt som de handlemuligheder, der stilles til rådighed er acceptable for barnet, og sproget benævner interaktionsformer, som kan besættes libidinøst, bliver sproget det Lorenzer kalder et symbolsprog (Lorenzer 1972) i modsætning til tegnsproget, der benævner det, der må fortrænges og som derfor ikke peger tilbage på sansekonkrete erfaringer. I tegnsproget er der sket et brud mellem sprog og erfaring.

Symbolsproget vil pege tilbage på et væld af sceniske erfaringer, også erfaringer, der ikke uden videre kan udtrykkes inden for den diskursive orden. Sproget peger altså både udad og indad. Udadtil begrænses det af de diskursivt givne muligheder; men post- strukturalismen lærer os jo også, at diskurserne ikke er éntydige, konsistente eller uden sprækker. Det peger også indad på et væld af scenisk erfaring, der kan stride mod den kønnede orden, som vi er en del af. Begær efter at træde uden for kulturens kønnede rammer kan hente næring i den infantile erfaring og fantasi, og selvfølgelig ikke bare den infantile. I det konkret levede liv vil der være mangetydige erfaringer, der kan forbinde sig med tidligere erfaringer. Barndom er ikke skæbne eller den er det kun i særlige tilfælde - patologi findes. De tilskyndelser der ikke nødvendigvis er tilgængelige for bevidstheden er ikke enstrengede eller kausale, og de kan træde frem på scenen som synlige når det aktuelle livs muligheder udvides. Ønsket om at udvide spillerummet, tilskyndelsen til at gøre det, og den kreativitet, der skal bruges for at gøre det, kan trække på de erfaringer, der ikke kunne sprogliggøres, men som alligevel kunne forbinde sig med det symbolske sprog. Dette kan blandt andet ske gennem ikke-sproglige udtryksformer, det Lorenzer kalder præsentativ symbolik. Ikke at jeg naivt tror, at blot man undgår den sammenhængende fortælling, unddrager man sig den diskursive orden. Diskurser har mange virkemåder - ikke kun sproglige; men den sprækker ofte mere, når der ikke er ord på spil.

\section{PSYKOANALYSEN I EMPIRISK FORSKNING}

Vi må skabe os - subjektivere os - gennem de vidensregimer, der står til rådighed, også når vi forsøger os med alternative interaktive handlinger. Men diskurser er ikke kun regulerende, de bliver også libidinøst besat, de far subjektiv og emotionel betydning. Det betyder så på den anden side også, at diskursive bestemmelser kan fastholdes på trods af at de indskrænker subjektets handlemuligheder, og at de kan fastholdes på trods af konkrete erfaringer. Det var for eksempel tilfældet $\mathrm{i}$ en af de erhvervsskoleklasser, hvor jeg undersøgte matematikun- 
dervisning og -læring for nogle år tilbage (Grønbæk Hansen 1999).

Matematikkompetence var maskulint konnoteret og på trods af, at HTX-klassens absolut og ubestridte bedste til matematik var en pige, blev dette forhold benægtet på forskellige måder. Drengene hævdede, at der i parallelklassen var denne her fyr, der virkelig kunne matematik - og detroniserede dermed den skrappe pige. Pigerne var mere tilbøjelige til at ekskludere den skrappe pige fra kategorien pige ved at pege på, at hun ingen kæreste havde og ikke gik $\mathrm{i}$ modetøj. På trods af deres erfaringer i klassen citerede de konventionelle diskurser om køn og matematik, og det var vigtigt for dem. Det havde en betydelig subjektiv og emotionel betydning for dem, at få tolket situationen ind i de konventionelle diskurser. Der syntes at være noget vigtigt på spil for eleverne, der syntes at være investeret en stor portion emotion i et subjektivitetsprojekt, der fastholder nogle forholdsvist snævre diskurser om køn.

At bruge psykoanalyse i analyse af empirisk forskning, når denne som her er deltagerobservation og gruppeinterviews er en vanskelig sag. Faren for overfortolkninger og dermed fortolkende overgreb på de mennesker man iagttager og samtaler med er nærliggende. Denne form for forskning adskiller sig klart fra den egentlige psykoanalyse, hvor analysanden deltager i de tolkende processer. Psykoanalytiske tolkninger der bygger på empiriske iagttagelser må altid være prøvende og forsøgende; det er bud på mulige forståelser. På den anden side, når man møder en voldsom modstand mod at sige det som er indlysende, må man formode at der er andet end konventionelle diskurser på spil.

Det synes at være sådan, at børn føler sig utilpasse ved brud på konventionelle diskurser og diskursive kategorier. Bronwyn Davies (1989) beretter om en episode, hvor en gruppe mindre skolebørn får læst et eventyr, hvor eventyrets sædvanlige nar- ration er brudt, således at det er prinsessen, der frelser prinsen fra dragen. Det er hende, der er den aktive, den der tager heltens rolle. Da børnene bagefter taler om eventyret foregår der en intens fortolkning med henblik på at genoprette den velkendte narration. Jeg kom til at tænke på den historie, da jeg for et stykke tid siden fik zappet ind i en udsendelse om nogle mindre skolebørn, der skulle i gang med et teaterstykke. De skulle spille H.C. Andersens "Snedronningen" og intervieweren spurgte en af drengene om han kendte eventyret, og han fortalte, at det jo handlede om den her dreng, der blev bortført af snedronningen og taget med til hendes slot. Der skulle han løse en gåde for at blive fri, og det lykkedes ham til sidst, og så kunne han tage hjem. Se, det er lidt af en fortolkning. I H.C. Andersens eventyr befinder den lille Kay sig i randområderne af handlingen, det er den lille Gerda der drager ud for at finde Kay, der optager størstedelen af fortællingen. Lille Gerda må slippe væk fra de røvere, der fanger hen$\mathrm{de}$, hun må ride på et rensdyr $\mathrm{i}$ bidende kulde og kxmpe mod snedronningens istropper for at nå frem til Kay. Alt dette forsvinder i drengens genfortælling, hvor Kay fastholder sin aktive helterolle, og vi igen får placeret kønnene i de konventionelle former. ${ }^{2}$

Det kan se ud som om, det er meget vigtigt for børn at fastholde de diskursive rammer for køn, sådan som de traditionelt er givet. Måske skal vi se det, som en meget stor subjektiv investering $\mathrm{i}$ deres indordning i de givne diskurser, og måske også som et tegn på at der er givet smertelige afkald for at ordne sig ind og undgå udgrænsning.

Begæret virker ikke bare destabiliserende på den diskursive orden, det kan også forbinde sig med denne orden og virke stabiliserende på den. Som sagt, begær og fantasi behøver ikke at virke i progressionens eller emancipationens tjeneste. De subjektpositioner der tilbydes gennem forskellige diskurser forbinder sig med dybere lag i subjektet 
og kan således opleves som havende mere eller mindre autencitet. At noget erfares som autentisk, altså forbinder sig med subjektive ønsker og begær behøver altså heller ikke betyde, at det nødvendigvis er noget, der udvikler ens handlemuligheder. Men det er herfra vi kan hente tilskyndelsen og fantasien der gør det muligt at benytte de diskursive muligheder kreativt og legende.

Det er ikke min mening at forsøge mig med egentlige analyser af de subjektive investeringer, der er på spil hos børnene, mit xrinde er blot at pege på det forhold, at en poststrukturalistisk analyse kan vise de diskurser om køn, der er på spil her og hvordan børnene positioneres og positionerer sig gennem deres særlige tolkning. Men de subjektive betydninger fanges ikke af denne analyse. Naturligvis ville en psykoanalytisk inspireret analyse heller ikke udtømme materialet. Der er altid noget tilbage vi ikke kan få fat i, sådan må det være. Men især hvis analysen skal bruges til forandring af praksis vil det være vigtigt at forstå de emotionelle betydninger af bestemte relationer, og at forstå at den emotionelle betydning af en konventionel diskurs ikke behøver at være konventionel.

Så vidt de muligheder sammentænkning af poststrukturalisme og psykoanalyse giver for at forstå de kønnede betydninger, jeg vil også kort og afslutningsvis pege på hvordan selve det empiriske arbejde kan lade sig inspirere af psykoanalysen.

Poststrukturalismen peger på, at forestillingen om objektivitet er en illusion. Den historie der fortælles gennem den empiriske forskning fortælles fra en position. Når forskeren træder ind i sit empiriske felt er det ikke som en desintereeseret indsamler af fakta, men som et levende subjekt der er indlejret $\mathrm{i}$ forskellige diskurser og som har bestemte interesser $\mathrm{i}$ feltet. Resultatet af forskningen er et tilbud om at se på feltet fra forskerens ståsted, et ståsted der naturligvis gerne skal lade sig rokke gennem processen. Det kræver selvrefleksion af forske- ren, både $\mathrm{i}$ indsamlingsfasen og $\mathrm{i}$ analysearbejdet. Men denne selvrefleksion fremstår ofte som en forsikring om at refleksionen er nødvendig og til stede, uden at det helt fremgår hvordan.

Vender vi os mod psykoanalysen, giver den et bud på hvordan man mere direkte kan arbejde med forskersubjektiviteten i det empiriske arbejde. Refleksioner over overføring og modoverføring er en integreret del af den analytiske proces. I sit arbejde med at forstå arbejderpigers brug af og fascination af populærkulturen, beretter Valerie Walkerdine (1997) hvordan de i forskningsgruppen udforskede egne emotioner, sådan som de opstod i processen, og hvordan disse refleksioner bidrog til at bringe analyserne videre. Det vil være kendt for de fleste forskere, at det empiriske arbejde i felten er nok så emotionelt ladet. Man forbliver ikke uberørt af en samtale eller diskussion, selvom man deltager som forsker. De interviewede kan vække voldsom sympati eller de kan vække direkte afsky eller modvilje hos forskeren. De udforskede kan blive genstand for allehånde modoverføringer fra forskerens side, ligesom forskeren vil blive fortolket og være genstand for overføringer fra de udforskedes side. I den forskningsgruppe Walkerdine beskriver, drejede det sig for eksempel om, at der var noget forskeren ikke ville høre, på trods af at det var relevant for undersøgelsen og de interviewede ønskede at fortælle om dette. Nogle historier provokerede forskerne i den grad, at de ikke magtede at analyserne materialet, de overså konsekvent bestemte passager i de interviewudskrifter de senere skulle bearbejde.

Her er det vigtigt at reflektere over de følelser, som de interviewede vækker. At prøve at gøre sig klart hvad overføringer og modoverføringer trækker på af erfaringer, ønsker og fantasier. Det kan være med til at bringe nye indsigter $\mathrm{i}$ det analytiske arbejde, fordi det kan tvinge forskeren selv ud af konventionelle tænkninger - og heller ikke 
poststrukturalister kan unddrage sig sådanne, heller ikke når det drejer sig om køn.

Målet her er at vise, at psykoanalysen ganske vist overskrider poststrukturalismens rammer, men gør det ved at beskxftige sig med det, der udelukkes af de diskursivt ordnede interaktioner og relationer. Det er muligt at bruge af psykoanalysens grundliggende antagelser uden at forfalde til essentialisme, determinisme eller entydig kausal tænkning. Målet var desuden at sandsynliggøre, at skal vi forstå kønnede udtryk og tolkninger, er det nødvendigt at gå videre end poststrukturalismens rammer ved at finde de subjektive begrundelser for bestemte måder at gøre køn på, og for at kunne indkredse alle de forandrende potentialer.

\section{Noter}

1. Jf. Kirsten Gomard m.fl.: "Kønsblik", DPU 2001 og Inge Henningsen m.fl.: "Reduktionisme og kønsfordeling i forskerverdenen”, København 1998.

2. En nærmere tolkning af eventyret viser ganske vist, at de traditionelle kønnede konnotationer bliver opretholdt på en anden måde. Lille Gerda repræsenterer det følende, kærlige og opofrende, mens Kay er den kolde forstand; men denne pointe er nok for subtil til at blive accepteret af børnene.

\section{LITTERATUR}

- Bjerrum Nielsen, H.: „Den magiske blokk - om kjønn og identitetsarbeid", in Psyke og Logos $1 / 1994$

- Bjerrum Nielsen \& Rudberg: Psychological Gender and Modernity, Oslo 1994

- Butler, J.: Bodies that Matter: on the Discursive Limits of "Sex", Routledge, New York, 1993

- Butler, J.: Gender Trouble: Feminism and the Subversion of Identity, Routledge, New York 1990

- Chodorow, Nancy: The Power of Feelings, Los Angeles 1999

- Davies, Bronwyn: Frogs and Snails and Feminist Tales. Preschool Children and Gender", New South Wales 1989

- Davies, B. \& Harré, R.: "Positioning: the Discur- sive production of selves", in Journal for the Theory of Social Behaviour", 20/1990

- Foucault, M.: The Order of Things - Archaeology of the Human Sciences, New York 1970

- Foucault, M.: The Archaeology of Knowledge es the Discourses on Language, G.B. Tavistock Publications 1972

. Freud, S.: Über die weibliche Sexualität, Frankfurt am Main 1972

- Freud, S.: Briefe an Wilhelm Fliess 1887-1914, Frankfurt am Main 1986

- Hansen, Kirsten Grønbæk: „Hvad kvalificerer skolen til? Og hvordan?", in Rask Eriksen, m.fl. (red.): Kvalifikationer. Definitioner af ord eller relationer mellem mennesker, Munksgaard 1999 - Lorenzer, Alfred: Sprachzerstöring und Rekonstruktion, Frankfurt am Main 1970

- Lorenzer, Alfred: Die Wabrheit der Psychoanalytischen Erkenttniss, Frankfurt am Main, 1974

- Lorenzer, Alfred: Sprachspiel und Interaktionsformen, Frankfurt am Main 1977

- Lorenzer, Alfred: "Barndom", in Kontext $41 / 1981$

- Parker, Ian: Psychoanalytic Culture. Psychoanalytic Discourse in Western Society, SAGE, London 1997 - Søndergaard, D.M.: "Subjektivering og desire begreber på empirisk arbejde i akademia", in Psyke og Logos $1 / 2002$

. Torok, Maria: "The Meaning of "Penis Envy" in Women", in Saguaro (ed): Psychoanalysis and Woman - a Reader, London 2000

- Walkerdine, V.: Daddy's Girl. Young Girls and Popular Culture, MacMillan, London 1997 - Winnicott, D.W.: The Maturational Processes and the Facilitating Environment, The Hogarth Press, London 1972

\section{SUMMARY}

Poststructuralism has played a major role in the revival of gender research during the 90s and into the new millennium. Speaking from the position of the discoursively excluded and rejecting the self-understanding of traditional science as an objective, impartial uncovering of the true nature of the phenomena in question, it is possible to deconstruct and destabilize the conventional discourses on gender and the borders of legitimate gendered actions. Poststructuralist gender research should be welcomed as a renewal of research and as a challenge to more traditional science. 
Psychoanalysis has often been the scapegoat when poststructuralists point out that traditional gender science ends up in essentialism, determinism and one-dimensional causality. This essay shows that this may prove - at least partly - right for some interpretations of psychoanalysis, but that psychoanalysis fundamentally, even in Freud's own work, is about understanding male and female as sometbing you become and not as an essential inner quality based on biological sex. This essay takes it starting point in Alfred Lorenzer's interpretation of psychoanalysis, where subjectivity is seen as a result of internalisation in- teractions and their subjective meanings. Subjective structures are manifold, contingent, and flexible and language is seen as a conforming of interaction to cultural discourses. Symbolic language will, however, point back to interactions and meanings that have been excluded from the cultural discourses and the creativity of the unconscious processes. Language points two ways. It points into the cultural possible discourses and it points to the subjective meanings of the person.

Kirsten Grønbæk Hansen lektor ved Psykologi, RUC 